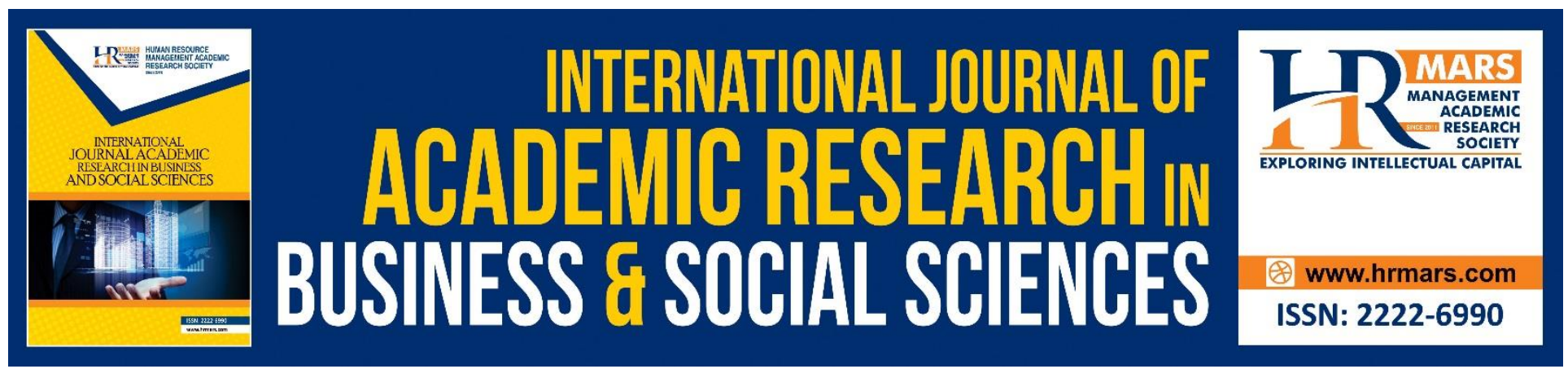

\title{
Impacts of NGOs Microfinance on Women Empowerment in Northern Pakistan
}

\section{Rossazana Ab-Rahim, Saif-Ul-Mujahid Shah \& Samira Raki}

To Link this Article: http://dx.doi.org/10.6007/IJARBSS/v8-i12/4987

DOI: $10.6007 /$ IJARBSS/v8-i12/4987

Received: 14 Nov 2018, Revised: 13 Dec 2018, Accepted: 15 Dec 2018

Published Online: 16 Dec 2018

In-Text Citation: (Ab-Rahim, Shah, \& Raki, 2018)

To Cite this Article: Ab-Rahim, R., Shah, S.-U.-M., \& Raki, S. (2018). Impacts of NGOs Microfinance on Women Empowerment in Northern Pakistan. International Journal of Academic Research in Business and Social Sciences, 8(12), 1-13.

Copyright: (C) 2018 The Author(s)

Published by Human Resource Management Academic Research Society (www.hrmars.com)

This article is published under the Creative Commons Attribution (CC BY 4.0) license. Anyone may reproduce, distribute, translate and create derivative works of this article (for both commercial and non-commercial purposes), subject to full attribution to the original publication and authors. The full terms of this license may be seen

at: http://creativecommons.org/licences/by/4.0/legalcode

\section{Vol. 8, No. 12, 2018, Pg. 1 - 13}

Full Terms \& Conditions of access and use can be found at http://hrmars.com/index.php/pages/detail/publication-ethics 


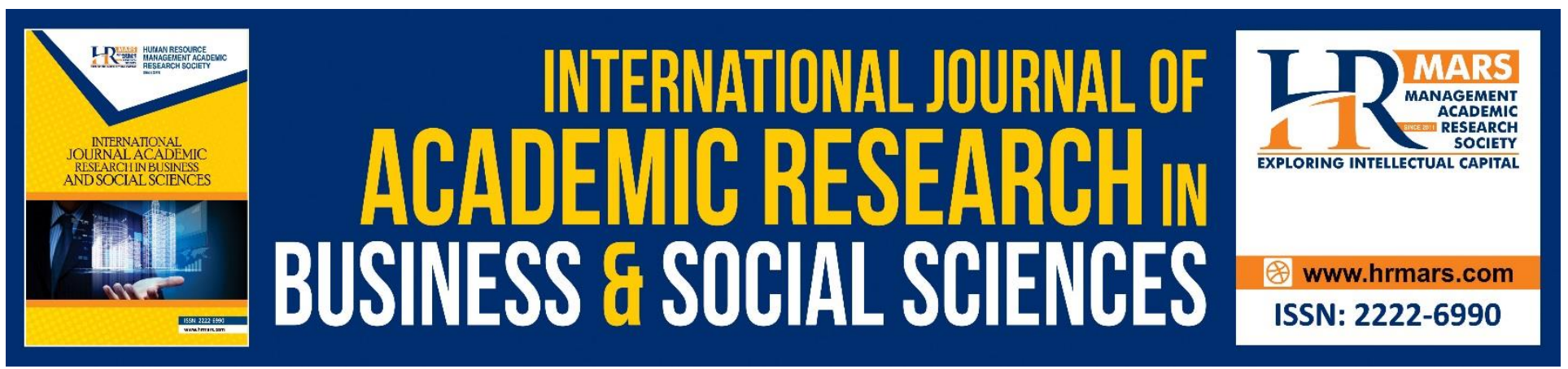

\title{
Impacts of NGOs Microfinance on Women Empowerment in Northern Pakistan
}

\author{
Rossazana Ab-Rahim, Saif-Ul-Mujahid Shah \& Samira Raki \\ Faculty of Economics \& Business, Universiti Malaysia Sarawak, Sarawak, Malaysia. \\ Email: arrossazana@unimas.my
}

\begin{abstract}
The aim of this paper is to investigate the role of NGOs microfinance in women empowerment in the Northern Pakistan. A total number of 309 beneficiaries were selected form three NGOs microfinance (Biyar Local Support Organization, Garamchashma Area Development and Integrated Chitral Development Programme). Quantitative primary data was adopted while the partial least squaresstructural equation modelling (PLS-SEM) was used to analyze the data collected. A logistic test was also performed to estimate the microfinance impact on women empowerment. The results show microfinance program has boosted the confidence level and the decision making power of the beneficiaries. In addition, respondents are able to make choices regarding the expenditure as well as to express their opinions in the community. The findings imply that more injection of micro loans by the government and NGOs so women can play a greater role in the community specifically to improve the wellbeing of the members of the households.
\end{abstract}

Keywords: Microfinance, Women Empowerment, Pakistan, NGOs.

\section{INTRODUCTION}

Women empowerment is one of the United Nation's Sustainable Development Goals that seeks to empower the women around the globe (United Nation, 2015), as women now represent 40 percent of the global labor force (World Bank, 2012). It is believed that microfinance as a sector plays a significant role in boosting economic dependency for women. According to Sujatha and Malyadri (2015), microfinance also enables women to gain greater social capital. At the same time, microfinance helps women in mitigating poverty (Zhang, 2017). Microfinance is basically loans to the under privileged people who are unable to get loans form the financial markets like banks. Government agencies and non-governmental organizations (NGOs) in recent years play an important role in the delivery of micro loans to the clientele especially to the women in order to empower them (Sultana et al., 2017). Microfinance not only provides credit facilities, but at the same time, empowers the poor especially women in terms of confidence, independent decision making, creation of awareness as well as integrates them socially and economically into the mainstream of the economy. 
By 2013, 211 million clients had received 3,098 microfinance assistance and 94 million borrowers were women (Microcredit Summit Campaign Report, 2015). In many developing countries, women are the lower paid majority and have a higher unemployment rate than men as compare to developed countries (World Bank, 2009). Women empowerment has become central issue of many countries around the globe and poverty is regarded as the main obstacle of women empowerment (Sultana et al., 2017). Authors have defined empowerment in different ways. According to Sen (1993), empowerment is echoed in a person's capability set which depends on factors such as personal characteristics of a person, proper food, good health, good shelter and social arrangements. Another view of empowerment is that, empowerment constitutes three dimensions: resources, agency, and achievements (Kabeer, 1999). The former refers to access and future claims to the material, human and social resources while agency means the process of decision making, negotiation and the latter is about well-being outcomes. From the psychological point of view, empowerment is control over oneself and the situations in which one lives (Francina \& Joseph, 2013). Empowerment is mostly measured in terms of relative and absolute wellbeing. Relative wellbeing is observed in terms of status of women in society; in terms of decision making, control over assets, income and loan taken whereas the latter is viewed in terms of literacy, nutrition, employment, ownership of assets and cloths (Ali \& Hatta, 2012). Previous studies also indicate that women play a significant role of women in effective resource allocation in households, such as child's health and educational outcomes (Duflo, 2012; World Bank, 2012).

The impact of microfinance on poverty has strongly been debated (Banerjee, 2013; Roodman; 2012; Morduch, 2011; Shakya, 2016) while the results of past studies on women empowerment have remained ambiguous (Ali \& Hatta, 2012; Ngo \& Wahhaj, 2012; Shakya, 2016). A number of studies deal with the positive impact of microfinance on women empowerment (Ahmed et al., 2011; Chowdhury and Chowdhury, 2011 Garikipati, 2012; Fofana et al., 2015; Mazumder \& Lu, 2015; Vinodhini \& Vaijayanthi, 2016; Karlan et al., 2017). Islam (2014) investigated the impact of microfinance on the employment and empowerment of rural women and the results showed a positive and significant effect on generating employment but approximately zero impact on empowerment of borrowers. However, Jamal et al. (2016) discovered a significant impact of microfinance on women empowerment both in social and economic aspects. Bali Swain and Wallentin (2017) found a significant correlation between women's empowerment and autonomy in their decision-making, social networking, communication, and political participation respectively; while Sultana et al. (2017) offered support to the positive effect of microfinance intervention on social empowerment of women. Much recent study, Widiyanti et al. (2018) found that the appropriate way to solve the issue of woman poverty is women empowerment through micro-financing program.

On this note, Rahman et al. (2017) and Porter (2016) suggested microfinance improved women's financial base and enhances their economic contribution to their families and their community. The mentioned studies also showed that microfinance increases bargaining power, decision making, welfare, reduces subordination, as well as strengthens women's voice. These findings are in the same vein with the findings from a stream of studies (Graflund, 2013; Gibbs et al., 2018; Khan \& Sajid, 2011; Muhammad et al., 2012; Nawaz, et. al., 2012; Weber \& Admad, 2014). On the contrary, another 
stream of studies indicate microfinance is not an influencing factor as far as poverty is concerned (Adu-Okoree 2012; Van Rooyen et al., 2012; Duvendack et al., 2014; Vaessen et al., 2014; Sujatha \& Matyadri, 2015; Al-Mamun et al., 2014; Stewart et al., 2010,). In addition, women faced domestic violence due to the credit weekly repayment (Ahmed et al., 2001; Ahmed, 2005; Wrigley-Asante, 2011; Naved \& Persson, 2005). A study on the impact of microfinance on empowerment conducted in Bangladesh revealed that few beneficiaries were empowered as they were able to utilize the loan in income generating activities (Akmam \& Islam, 2017). Hence, it is interesting to investigate the impacts of microfinance on women empowerment in Northern Pakistan The remainder of this study proceeds as follows. Next section offers the theoretical studies as well as a review of empirical studies on the microfinance and women empowerment follows by the data and methodology section. The subsequent section presents the empirical results while the last section concludes the paper and presents the future research directions.

\section{LITERATURE REVIEW}

Microfinance is currently an effective tool not only in providing financial assistance to the poor but also helps in empowering women (Annan, 2018). Microfinance basically refers to small size loans to the poor people especially women to enhance their income generation potential through starting their own income generating activities (Microcredit Summit, 2007). Empowering women through microfinance leads to lasting positive economic and political change (Mahmood et al., 2014).

Empowerment is a process of transformation where an individual gradually changes from a state of helpless to a position of relative control by taking control over his destiny and making use of his immediate resources for sustainable improvement in his livelihood and better standards of living (Rappaport, 1981). Microfinance as a mean of individual empowerment and poverty reduction has surrounded the discussion on the empowerment theory. The empowerment theory is a substitute to the mainstream theories of development that give more importance to growth and rapid industrialization in addressing the poverty situation in developing countries (Ergano \& Nurfeta, 2006). In such situation, a majority of the poor are exploited and pushed into a downward spiral of resource deficit, thus falling into the poverty trap. Myrdal (1968) described such a situation as the vicious cycle in which the poor will remain in poverty unless they do not try to come out.

The lack of expectation leads to other options to the development approach, hence the empowerment theory stresses on the need of poor people's participation at the grassroots level in the decision-making process on a larger scale against development policies planned by politicians and international institutions that are developed for their own good will (Friedmann, 1992). The empowerment theory encourages the poor to gain capabilities by taking part in the development process and taking control of their own destinies in order to achieve sustainable development and ultimately, decrease poverty. The empowerment theory has gained importance among national and international agencies, with most of its debate surrounding topics of development, awareness, economic and social betterment, power relations, poverty alleviation, and empowerment. The contributions of Friedmann, Rappaport, Zimmerman, Chambers and Myrdal of the same category are of paramount importance. However, greater emphasis is placed on Friedmann's (1992) work titled 
'Empowerment: The Politics of Alternative Development' wherein the great scholar provided the basis for an alternative development approach as defined in the politics of empowerment by asserting universal human awareness and rights of people within a given social setting. The focus is on such households that are disgraced and deprived of basic needs in the society, and all classes of disempowered people; men and women alike who constitute a majority of their political communities.

Friedmann explains empowerment in terms of power relations consist of three forms. First, the awareness, knowledge, social power, abilities, participation in communities' gatherings and access to financial resources without any form of community discriminations. The second form of power is political power which means independence and involvement in the decision-making process. The last form of power is psychological power which takes into account individual potential and their reasoning that influences political and social power. Narayan (2002) added that empowerment is the extension of resources and abilities to needy people for them to take part in social activities that affect their lives. The empowerment theory's contribution towards development cannot be overemphasized by not considering the emergence of NGOs' microfinance projects all around the world and their impacts on the local community at large (Clarke et al., 2003).

Numerous studies have postulated a significant positive impact on the association of microfinance and women empowerment (Pitt \& Khandkar, 1998; Khandkar, 2005). Previous studies confirm that women play a great role in the decision making process of families (Duflo 2012; World Bank 2012) and due to the lack of capital, confidence and self-esteem many women are living in poverty (Mahmood et al., 2014). Microfinance has become a means to enhance the life standard of the poor women (Widiyanti et al., 2018). As previous studies (Porter, 2016; Vinodhini, \& Vaijayanthi, 2016) show, microfinance has played as an effective tool in increasing the self-esteem and income level of the beneficiaries. In addition, there are studies to report that the micro loan has developed the selfconfidence and independence among women (Khatun \& Hasan, 2015; Morgan \& Coombes, 2013; Hansen, 2015), that past studies have used different indicators to measure empowerment. These indicators include self-esteem (Basargekar, 2009; Kato \& Kratzer, 2013; Nikkhah et al., 2010; Hansen, 2015); self-confidence (Pitt et al., 2006; Pitt et al., 2003; Burra et al., 2005; Kim et al., 2007); self-efficacy (Schuler et al., 2010; Kato \& Kratzer, 2013; Herath et al. 2015; Ahmad \& Ahmad, 2016); decision-making (Ashraf et al., 2008; Blumberg, 2005; Hashemi \& Rosenberg, 2006; Banerjee et al., 2015), and mobility (Parameswaran, 2005; Bali Swain \& Wallentin, 2009; Schuler et al., 2010; Kato \& Kratzer, 2013; Datta, 2015).

Based on the above discussed, the following hypotheses are developed:

H1: The Impact of Microfinance on Mobility

H2: The Impact of Microfinance on Self-esteem

H3: The Impact of Microfinance on Decision Power

H4: The Impact of Microfinance on Self-confidence 


\section{METHODOLOGY}

The main objective of the present paper is to investigate the impact of microfinance on women empowerment. This study is based on a field survey conducted in Northern Pakistan and the list of the beneficiaries was obtained from three NGOs microfinance namely Biyar Local Support Organization, Garamchashma Area Development and Integrated Chitral Development Programme and a total 308 respondents was selected from the list. This study is conducted using descriptive research design as it employed descriptive statistics during data presentation, the correlation and linear regression research design has been employed to test hypothesis. The study adopted quantitative approach because the study was based on variables that were estimated with numbers and analyzed with statistical procedures to analysis the contribution of NGO microfinance. The empowerment was measured based on four indicators; mobility, decision making, self-esteem, and self-confidence. Structural equation modelling was used to examine the impact of microfinance on empowerment. The data collection started in a month of April, 2017 and continued up to the end of August 2017. The data was collected through a self-administered and personally administer questionnaire.

\section{RESULTS AND DISCUSSION Measurement Model}

The measurement model includes items such as convergent validity, discriminant validity, internal consistency, and reliability (Hair et al., 2014) whereby reliability was checked based on factor loading, and each factor loading was considered to be bigger then 0.4 (Hair et al., 2011). The SmartPLS 3.0 (M3) is used to assess the measurement and structural model

Table 1. Convergent Validity

\begin{tabular}{lcccc}
\hline Construct & Loading & CR & AVE & $\begin{array}{c}\text { Convergent } \\
\text { Validity } \\
\text { (AVE > 0.5) }\end{array}$ \\
\hline Self-Confidence & $0.673-0.844$ & 0.882 & 0.602 & YES \\
Decision Power & $0.737-0.887$ & 0.884 & 0.656 & YES \\
Self-Esteem & $0.865-0.923$ & 0.951 & 0.794 & YES \\
Mobility & $0.764-0.956$ & 0.914 & 0.782 & YES \\
\hline
\end{tabular}

As indicated in Table 1, most of the items have loading more than 0.04 that satisfies the criteria of item reliability. Similarly, the internal consistency was measured using the composite reliability. It means that all indicators measured the same latent construct, and that each indicator should be assigned a different score higher than 0.70 (Hair et al., 2013). The values for composite reliability that appear in Table 1 are above the threshold of .70. Furthermore, the convergent validity is measured through average variance extracted (AVE) and according to Chin (1998) AVE should at least be 0.50 or more. Table 1 also shows that all the constructs have achieved the minimum AVE of 0.50 (Chin, 1998), which represents the capacity of the construct to explain more than half of the variance of its indicators on average (Kramer, 2007). 
INTERNATIONAL JOURNAL OF ACADEMIC RESEARCH IN BUSINESS AND SOCIAL SCIENCES

Vol. 8, No. 12, Dec, 2018, E-ISSN: 2222-6990 @ 2018 HRMARS

\section{Discriminant Validity}

Discriminant validity means the degree to which each construct differed from the other constructs. When the construct captures phenomena that other constructs fail to capture, the case is called High discriminant validity. Discriminant validity measure makes use of the Heterotrait-monotrait ratio of the correlations (HTMT) (Henseler et al., 2015). Table 2 shows the results of the discriminant validity analysis and all the values of the constructs are below the threshold of 0.90 (Teo et al., 2008).

Table 2. Discriminant Validity

\begin{tabular}{lcccc}
\hline & $\begin{array}{c}\text { Self- } \\
\text { Confidence }\end{array}$ & $\begin{array}{c}\text { Decision } \\
\text { Power }\end{array}$ & Self-Esteem & Mobility \\
\hline Self-Confidence & 0.740 & & & \\
Decision Power & 0.729 & 0.433 & & \\
Self-Esteem & 0.732 & 0.519 & 0.379 & \\
Mobility & 0.897 & 0.466 & 0.231 & 0.466 \\
\hline
\end{tabular}

\section{Structural Model}

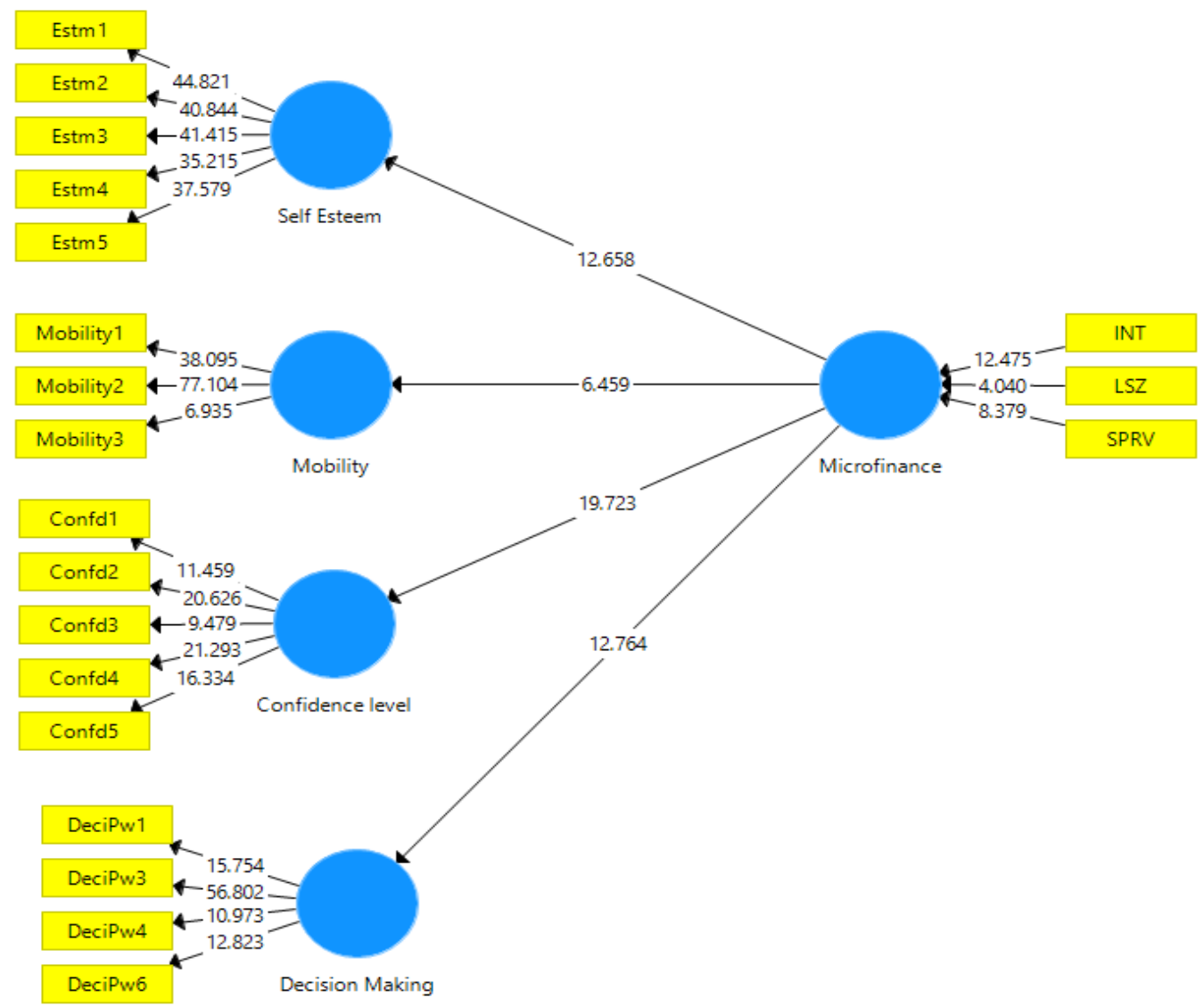

Figure 1: Structural Model 
INTERNATIONAL JOURNAL OF ACADEMIC RESEARCH IN BUSINESS AND SOCIAL SCIENCES Vol. 8, No. 12, Dec, 2018, E-ISSN: 2222-6990 @ 2018 HRMARS

Table 3. Hypothesis Testing

\begin{tabular}{llclc}
\hline Hypothesis & \multicolumn{1}{c}{ Relationship } & Beta & t-value & Result \\
\hline H1 & Microfinance $\rightarrow$ Mobility & 0.409 & $6.396^{* *}$ & Yes \\
H2 & Microfinance $\rightarrow$ Self-Esteem & 0.638 & $12.445^{* *}$ & Yes \\
H3 & Microfinance $\rightarrow$ Decision Power & 0.502 & $12.798^{* *}$ & Yes \\
H4 & Microfinance $\rightarrow$ Self-Confidence & 0.68 & $18.303^{* *}$ & Yes
\end{tabular}

${ }^{*} \mathrm{p}<0.05, \mathrm{t}$-value greater than 1.645-2.32 ( 1 tailed) ${ }^{* *} \mathrm{p}<0.01$, $\mathrm{t}$-value greater than 2.33 ( 1 tailed)

\section{CONCLUSION}

This study examines the impact of microfinance on the women's empowerment using various indicators. Quantitative data was collected from 3 NGOs in the Northern areas of Pakistan. The results of this study show that microfinance is an effective tool for empowering women. It has brought positive impact on women empowerment and has enhanced their status in the household and surrounding neighboring. Most of the beneficiaries' decision power increased within the household, and they were able to make decisions on their own. The findings also show that participation, selfesteem and self-efficacy have increased after joining the microfinance organization. As a result of the contribution in the household expenditure, the beneficiaries are treated respectfully by their families. In addition, the beneficiaries are also more confident in making family decisions and giving their opinion on family matters. Overall, the findings show microfinance brings positive impacts to women. This study offers an avenue to future studies as it is recommended that women empowerment should be analyzed on the basis of economics and social aspects. In the nutshell, this study makes two major contributions. At the contextual level, this study has shed lights on the impacts of microfinance on women empowerment in developing countries particularly Pakistan. Theoretically, this study confirms the theory of the empowerment whereby the livelihood of the borrowers is gradually changing from the state of poverty and helpless to the position of relative control by making use of the loan for their sustainable improvement.

Acknowledgement: This work was supported by Ministry of Education, Malaysia and Universiti Malaysia Sarawak [grant numbers F01/FRGS/1607/2017].

\section{REFERENCES}

Ahmad, N. M., \& Ahmad, M. M. (2016). Role of Microcredit towards socioeconomic empowerment of Pakistani urban women. The Anthropologist, 26(3), 189-197.

Ahmed, S. M. (2005). Intimate partner violence against women: Experiences from a woman-focused development programme in Matlab, Bangladesh. Journal of Health Population and Nutrion, 23(6) 95-101

Ahmed, F., Siwar, C., \& Idris, N. A. H. (2011). Sustainable livelihood amongst rural women through microcredit programme in Bangladesh. Australian Journal of Basic and Applied Sciences, 5(7), 116-120.

Ahmed, M. S., Chowdhury, M., \& Bhuiya, A. (2001). Micro-credit and emotional well-being: Experience of poor rural women from Matlab, Bangladesh. World Development, 29(11), 1957- 1966. 
INTERNATIONAL JOURNAL OF ACADEMIC RESEARCH IN BUSINESS AND SOCIAL SCIENCES

Vol. 8, No. 12, Dec, 2018, E-ISSN: 2222-6990 @ 2018 HRMARS

Akmam, W., \& Islam, M. F. (2017). Non-governmental organizations' contributions to poverty reduction and empowerment of women through microcredit: A case of a village in Gaibandha district, Bangladesh. In Shibusawa, H. (Eds.) Socioeconomic Environmental Policies and Evaluations in Regional Science (pp. 411-425). Singapore: Springer.

Ali, I. \& Hatta, Z. A. (2012). Women's empowerment or disempowerment through microfinance: evidence from Bangladesh. Asian Social Work and Policy Review, 6(2), 111-121.

Al-Mamun, A., Mohammad Nurul, H. M., Sazali, A. W., \& Su, Z. (2014). Empirical investigation on the impact of microcredit on women empowerment in Urban Peninsular Malaysia. Journal of Developing Areas, 48(2), 287-306.

Annan, A. (2018). Microfinance Performance: The Dynamics Between Performance and Funding Sources Across Microfinance Institution Legal Charters and Age Groups (Executive Doctorate in Business). Georgia State University, United States.

Ashraf, N., Karlan, D., \& Yin, W. (2008). Female Empowerment: Impact of a Commitment Savings Product in the Philippines (No. Center Discussion Paper no. 949). New Haven.

Bali Swain R., and Wallentin F. Y. (2009). Does microfinance empower women? Evidence from selfhelp groups in India. International Review of Applied Economics, 2(3), 541-556

Bali Swain, R., \& Wallentin, F. Y. (2017). The impact of microfinance on factors empowering women: Differences in regional and delivery mechanisms in India's SHG programme. The Journal of Development Studies, 53(5), 684-699.

Banerjee A. V., Duflo E., Glennerster R., Kinnan C. (2015). The miracle of microfinance: Evidence from a randomized evaluation. American Economic Journal: Applied Economics. 7(3) 22-53.

Banerjee A. V. (2013). Microcredit under the microscope: What have we learned in the past two decades, and what do we need to know? Annual Review of Economics 5(2), 487-519.

Basargekar, P. (2009). Microcredit and a macro leap: An impact analysis of Annapurna Mahila Mandal (AMM), an urban microfinance institution in India. Journal of Financial Economics 7(1), 105120.

Blumberg, R. L. (2005). Women's Economic Empowerment as the “Magic Potion" of Development? (Paper presented at the 100th Annual Meeting of the American Sociological Association). Philadelphia.

Burra, N., Deshmukh-Ranadive, J., \& Murthy, R. K. (2005). Micro-credit, poverty and empowerment: Linking the triad ( $1^{\text {st }}$ ed). New Delhi: Sage Publications

Chin, W.W. (1998). The partial least squares approach to structural equation modeling. Modern Methods for Business Research, 295(2), 295-336.

Chowdhury, S. S., \& Chowdhury, S. A. (2011). Microfinance and women empowerment: A panel data analysis using evidence from rural Bangladesh. International Journal of Economics and Finance, 3(5), 86-91.

Clarke, G., Cull, R., Peria, M. S. M., \& Sanchez, S. M. (2003). Foreign bank entry: Experience, implications for developing economies, and agenda for further research. The World Bank Research Observer, 18(1), 25-59.

Duflo, E. (2012). Women empowerment and economic development. Journal of Economic Literature, 50 (4): 1051-79 
INTERNATIONAL JOURNAL OF ACADEMIC RESEARCH IN BUSINESS AND SOCIAL SCIENCES

Vol. 8, No. 12, Dec, 2018, E-ISSN: 2222-6990 @ 2018 HRMARS

Duvendack, M., Palmer-Jones, R., \& Vaessen, J. (2014). Meta-analysis of the impact of microcredit on women's control over household decisions: Methodological issues and substantive findings. Journal of Development Effectiveness, 6(3), 73-96.

Ergano, K., \& Nurfeta, A. (2006). Economic performance of case study dairy farm in Southern Ethiopia. Livestock Research for Rural Development, 18(1), 12-19.

Fofana, N. B., Antonides, G., Niehof, A., \& van Ophem, J. A. (2015). How microfinance empowers women in Côte d'Ivoire. Review of Economics of the Household, 13(4), 1023-1041.

Francina, P. X., \& Joseph, M.V. (2013). Women empowerment: the psychological dimension Rajagiri. Journal of Social Development, 5(2),45-64.

Friedmann, J. (1992). Empowerment: The politics of alternative development (3 ${ }^{\text {rd }}$ ed). Cambridge, USA: Blackwell Oxford.

Garikipati, S. (2012). Microcredit and women's empowerment: Through the lens of time-use data from rural India. Development and Change, 43(3), 719-750.

Gibbs, A., Jewkes, R., Karim, F., Marofi, F., \& Corboz, J. (2018). Understanding how Afghan women utilise a gender transformative and economic empowerment intervention: A qualitative study. Global Public Health, 2(4), 1-11.

Hair, J. F., Ringle, C.M. \& Sarstedt, M. (2011). PLS-SEM: Indeed, a silver bullet. Journal of Marketing Theory and Practice, 19(3), 139-151.

Hair, J. F., Ringle, C. M., \& Sarstedt, M. (2013). Partial least squares structural equation modeling: Rigorous applications, better results and higher acceptance. Long Range Planning 46(2), 1-12.

Hair, J. F., Hult, G.T.M., Ringle, C.M., \& Sarstedt, M. (2014). A primer on partial least squares structural equation modeling (PLS-SEM) (1st ed). Los Angeles,USA: Sage Publications.

Hansen, N. (2015). The development of psychological capacity for action: The empowering effect of a microfinance programme on women in Sri Lanka. Journal of Social Work, 21(71), 597-613.

Hashemi, S. M., \& Rosenberg, R. (2006). Graduating the Poorest into Microfinance: Linking Safety Nets and Financial Services (Focus Note No. 32). Washington, DC: Consultative Group to Assist the Poor (CGAP).

Henseler, J., Ringle, C. M., \& Sarstedt, M. (2015). A new criterion for assessing discriminant validity in variance-based structural equation modeling. Journal of the Academy of Marketing Science, 3(2) 1-21.

Herath, H. M. W. A., Guneratne, L. H. P., \& Sanderatne, N. (2015). Impact of microfinance on women's empowerment: A case study on two microfinance institutions in Sri Lanka. Sri Lanka Journal of Social Sciences, 38(1), 51-61.

Islam, M. S. (2014). Role of Grameen Bank's Microcredit in the Employment and Empowerment of Rural Borrower-women in Bogra District. Development Compilation,10(2), 95-108

Jamal, M. A., Raihana, A. K. A., \& Sultana, H. Y. (2016). Empowerment of Muslim women through microfinance and self-help groups: A case study of Chennai City. Asian Business Review, 6(2), 117-124.

Kabeer, N. (1999). Resources, agency, achievements: Reflections on the measurement of women's empowerment. Development and Change, 30(3), 435-464. 
INTERNATIONAL JOURNAL OF ACADEMIC RESEARCH IN BUSINESS AND SOCIAL SCIENCES

Vol. 8, No. 12, Dec, 2018, E-ISSN: 2222-6990 @ 2018 HRMARS

Karlan, D., Savonitto, B., Thuysbaert, B., \& Udry, C. (2017). Impact of savings groups on the lives of the poor. Proceedings of the National Academy of Sciences. Available at https://doi.org/10.1073/pnas.1611520114

Kato, M. P., and Kratzer, J. (2013). Empowering women through microfinance: evidence from Tanzania. Journal of Entrepreneurship Perspectives 2(4), 31-59.

Khan, S., \& Sajid, M. R. (2011). Women's empowerment through microcredit: A case study of district Gujrat, Pakistan. Academic Research International, 1(2), 332-354.

Khandker, S. R., (2005). Microfinance and poverty: Evidence using panel data from Bangladesh." World Bank Economic Review, 19(2), 263-86.

Khatun, F., \& Hasan, M. (2015). Social capital in microfinance: A critical investigation of Bangladesh. Journal of Emerging Trends in Economics and Management Sciences, 6(5), 315323.

Kim, J. C., Watts, C., Hargreaves, J. R., Ndhlovu, L. X., Phetla, G., Morison, L. A., et al. (2007). Understanding the impact of a microfinance-based intervention on women's empowerment and the reduction of intimate partner violence in South Africa. American Journal of Public Health, 97(13), 1794-1802

Kramer, M. P. (2007). Strategy and society: The link between competitive advantage and corporate social responsibility. Harvard Business Review, 80(5), 78-92.

Mahmood, S., Hussain, J., \& Matlay, H. (2014). Optimal microfinance loan size and poverty reduction amongst female entrepreneurs in Pakistan. Journal of Small Business and Enterprise Development, 21(2), 231-249.

Mazumder, M. S. U., \& Lu, W. (2015). What impact does microfinance have on rural livelihood? A comparison of governmental and non-governmental microfinance programs in Bangladesh. World Development, 68(3), 336-354.

Microcredit Summit Campaign Report (2007). Report on Microfinance available at http://www.microcreditsummit.org/uploads/resource/document/socr2007eng31514.pdf

Microcredit Summit Campaign Report (2015). Report on Microfinance available at https://stateofthe campaign.org /2015-report-tables-and-figures/

Morduch, J., (2011). Why Finance Matters. Science, 332(6035), 1271-1272.

Morgan, M., and Coombes, L. (2013). Empowerment and advocacy for domestic violence victims. Social and Personality Psychology Compass, 7(8), 526-536.

Muhammad, S., Shaheen, G., Naqvi, S., \& Zehra, S. (2012). Women empowerment and microfinance: A case study of Pakistan. African Journal of Business Management, 6(22), 6497-6503.

Myrdal, G. (1968). Asian Drama: An Inquiry into the Poverty of Nations (3 ${ }^{\text {rd }}$ ed). New Delhi, India. Kalyani Publishers.

Narayan-Parker, D. (2002). Empowerment and poverty reduction: A sourcebook. Washington DC, USA: World Bank Publications.

Naved R. T., Persson L. A. (2005). Factors associated with spousal physical violence against women in Bangladesh. Studies in Family Planning, 36(4), 289-300.

Nawaz, N., Jahanian, A., \& Manzoor, S. W. (2012). Empowering women through microcredit: A case study of Tameer microfinance bank, Bahawalpur. Journal of Economics and Sustainable Development, 3(6), 17-21. 
INTERNATIONAL JOURNAL OF ACADEMIC RESEARCH IN BUSINESS AND SOCIAL SCIENCES

Vol. 8, No. 12, Dec, 2018, E-ISSN: 2222-6990 @ 2018 HRMARS

Ngo, T. M. P., \& Wahhaj, Z. (2012). Microfinance and gender empowerment. Journal of Development Economics, 99(1), 1-12.

Nikkhah, H. A., Redzuan, M., \& Abu-Samah, A. (2010). The Effect of Women's Socio-demographic Variables on their Empowerment. Journal of American Science, 6(11), 426-434.

Parameswaran, M. P. (2005). Empowering people. (1st ed.). Delhi: Daanish Books.

Pitt, M. M., \& Khandker, S. R. (1998). The impact of group-based credit programs on poor households in Bangladesh: Does the gender of participant's matter? Journal of Political Economy, 106(5), 958-996.

Pitt, M. M., Khandker, S. R., \& Cartwright, J. (2006). Empowering Women with Micro Finance: Evidence from Bangladesh. Economic Development and Cultural Change, 54(4), 791-831.

Pitt, M. M., Khandker, S. R., Chowdhury, O. H., \& Millimet, D. L. (2003). Credit Program for the Poor and the Health Status of Children in Rural Bangladesh. International Economic Review, 44(1), 958-996.

Porter, M. (2016). Effects of Microcredit and Other Loans on Female Empowerment in Bangladesh: The Borrower's Gender Influences Intra-Household Resource Allocation. Agricultural Economics, 47(2), 235-245.

Rahman, M. M., Khanam, R., \& Nghiem, S. (2017). The effects of microfinance on women's empowerment: new evidence from Bangladesh. International Journal of Social Economics, 44(12), 1745-1757.

Roodman, D. (2012). Due diligence: An impertinent inquiry into microfinance. Washington, DC: Center for Global Development.

Rappaport, J. (1981). In praise of paradox: A social policy of empowerment over prevention. American Journal of Community Psychology, 9(1), 1-25.

Schuler, S. R., Islam, F., \& Rottach, E. (2010). Women's empowerment revisited: a case study from Bangladesh. Development in Practice, 20(7), 840-854.

Sen, A.K. (1993). Capability and well-being. In Nussbaum, M. and Sen, A.K. (edu., 30-53), The Quality of Life. Helsinki: World Institute of Development Economics Research.

Shakya, K. (2016). Microfinance and Women Empowerment. (Master Thesis), International Business.

Sujatha G., \& Malyadri P. (2015). Impact of microfinance on women empowerment: An empirical evidence from Andhra Pradesh. Journal of Entrepreneurship and Organization Management 4(2), 141-165.

Sultana, H. Y., Jamal, M. A., \& Najaf, D. E. (2017). Impact of microfinance on women empowerment through poverty alleviation: An assessment of socio-economic conditions in Chennai city of Tamil Nadu. Asian Journal for Poverty Studies, 3(2), 23-46.

United Nation (2015). Transforming our world: the 2030 Agenda for Sustainable Development. Available at http://unctad.org/meetings/en/SessionalDocuments/ares70d1_en.pdf

Vaessen, J., Rivas, A., Duvendack, M., Palmer Jones, R., Leeuw, F. L., Van Gils, G., \& Waddington, H. (2014). The effects of microcredit on women's control over household spending in developing countries: A systematic review and meta-analysis. Campbell Systematic Reviews, 10(8), 1-205.

Van Rooyen, C., Stewart, R., \& De Wet, T. (2012). The impact of microfinance in sub-Saharan Africa: A systematic review of the evidence. World Development, 40(11), 2249-2262. 
Vinodhini, R. L., \& Vaijayanthi, P. (2016). Self-help group and socio-economic empowerment of women in rural India. Indian Journal of Science and Technology, 9(27), 67-89.

Weber, O., \& Ahmad, A. (2014). Empowerment through microfinance: The relation between loan cycle and level of empowerment. World Development, 62(4), 75-87.

Widiyanti, E., Pudjihardjo, P., \& Saputra, P. M. A. (2018). Tackling poverty through women empowerment: The role of social capital in Indonesian women's cooperative. Jurnal Ekonomi dan Studi Pembangunan, 10(1), 44-55.

World Bank (2009). The International Centre for Settlement of Investment Disputes. Available at http://siteresources.worldbank.org/EXTAR2009/Resources/6223977-1252950831873/ AR 09 _Complete.pdf

World Bank (2012). World Development Report. Washington, DC. Available at https:// sitere sources.worldbank.org/INTWDR2012/Resources/7778105-1299699968583 /7786 210 1315936222006/Complete-Report.pdf.

Wrigley-Asante, C. (2012). Out of the dark but not out of the cage: women's empowerment and gender relations in the Dangme West district of Ghana. Gender, Place \& Culture, 19(3), 344363.

Zhang, Q. (2017). Does microfinance reduce poverty? Some international evidence. Journal of Macroeconomics, 17(2): 1-13. 